\title{
Can there be wrongful life at the end of life? German courts revisit an old problem in a new context
}

\author{
Ulrich Pfeifer (1) , ${ }^{1}$ Ruth Horn (1) ${ }^{2}$
}

'Pediatric Neurology and Metabolic Medicine, Center for Pediatric and Adolescent Medicine, Heidelberg University Hospital, Heidelberg, Germany ${ }^{2}$ The Ethox Centre, Wellcome Centre for Ethics and Humanities, NDPH, University of Oxford, Oxford, UK

Correspondence to Dr Ulrich Pfeifer, Pediatric Neurology and Metabolic Medicine, Center for Pediatric and Adolescent Medicine, Heidelberg University Hospital, 69120 Heidelberg, Germany; ulrich.pfeifer@med.uniheidelberg.de

\section{ABSTRACT}

This article discusses a recent ruling by the German Federal Court concerning medical professional liability due to potentially unlawful clinically assisted nutrition and hydration (CANH) at the end of life. This case raises important ethical and legal questions regarding a third person's right to judge the value of another person's life and the concept of 'wrongful life'. In our brief report, we discuss the concepts of the 'value of life' and wrongful life, which were evoked by the court, and how these concepts apply to the present case. We examine whether and to what extent value-of-life judgements can be avoided in medical decision-making. The wrongful-life concept is crucial to the understanding of this case. It deals with the question whether life, even when suffering is involved, could ever be worse than death. The effects of this ruling on medical and legal practice in Germany are to be seen. It seems likely that it will discourage claims for compensation following life-sustaining treatment (LST). However, it is unclear to what extent physicians' decisions will be affected, especially those concerning withdrawal of CANH. We conclude that there is a risk that LST may come to be seen as the 'safe' option for the physician, and hence, as always appropriate.

In April 2019, the German Federal Court of Justice (Bundesgerichtshof) rendered a judgement concerning medical professional liability due to potentially unlawful clinically assisted nutrition and hydration (CANH) at the end of life. ${ }^{1}$ This case raises important ethical questions for bioethical reflection, particularly with regard to a third person's right to make value judgments about another person's life and death.

The civil lawsuit concerned a man who died in 2011 at the age of 82 after having suffered from severe dementia for several years. After the patient's demise, his son sued the responsible general practitioner (GP). He claimed that the provision of $\mathrm{CANH}$, which the patient received by percutaneous endoscopic gastrostomy, prevented a natural death and prolonged his father's suffering.

From 1997, the patient's son, who lived abroad, had appointed a lawyer as the legal guardian of the patient. During the last years of his life, the patient lived in a nursing home, confined to bed and unable to communicate. He suffered from increasing spasticity and had multiple decubital ulcers. Repeated infections necessitated inpatient treatment. In 2006, CANH was started during an episode of dehydration. The patient's will regarding life-sustaining treatment (LST) was unknown. Between 2006 and 2010, the son made several unsuccessful attempts to persuade the GP and the direction of his father's nursing home to discontinue CANH. However, neither the son nor the guardian took the case to court to obtain the right to withdraw CANH. Eventually, the patient died in 2011 of aspiration pneumonia. He received CANH until his death.

In German medical law, plaintiffs must establish that a breach of duty caused a damage to the patient. $^{2}$ Accordingly, the plaintiff, the patient's son, made the following allegations: at least 2 years prior to the patient's death, his illness had taken an irreversible course, without hope of improvement. Therefore, CANH merely delayed the process of 'natural dying' and should have been discontinued. The plaintiff argued that the failure to discontinue CANH caused prolonged suffering for the patient and asked for $€ 100000$ in compensation for suffering and $€ 50000$ in indemnity.

The case was first heard before the Regional Court (Landgericht) ${ }^{3}$ and subsequently appealed in the Higher Regional Court (Oberlandesgericht). ${ }^{4}$ The Regional Court rejected the claim. It put the burden of proof on the plaintiff to demonstrate that the legal guardian would have actually agreed to withdraw CANH had this been recommended by the GP. It concluded that causation could not be established. Subsequently, the Higher Regional Court overturned the decision and ruled against the defendant. It affirmed both damage and causation, this time by putting the burden of proof on the defendant. Thus, both courts agreed that there was breach of medical professional duty because the GP neglected to regularly assess the medical indication of CANH as is required by the German Medical Association, ${ }^{5}$ but disagreed on damage and causation.

In contrast to the lower courts, the Federal Court emphasised that there was no non-pecuniary damage and thus questions of breach of duty and causation could be set aside. The judgement stressed the fact that no action or non-action (omission) of the GP could have improved the patient's life at this stage. Hence, the alleged damage was life itself and it was stated that,

no third person is entitled to a judgement about its value. It is therefore unthinkable to consider lifeeven survival afflicted with suffering-as a damage. ${ }^{1}$

Two ideas are crucial to the discussion of this case and both were considered at length by the courts: first, the concept of 'wrongful life', which informs a large portion of the verdict's legal reasoning. Second, the concept of the 'value of life' with regard to decisions made on behalf of incompetent patients. The latter point is especially pertinent, given the historical background with state-ordered euthanasia during the Nazi regime. 
In lawsuits involving wrongful life, the relevant question is whether living with pain can ever be considered a damage when compared with death. Typically, these cases concern the birth and life of a child with a congenital condition, whose parents claim that they would have terminated the pregnancy had they been informed about the foreseeable disability. The canonical case in German law, decided by the Federal Court in 1983, involved a girl with severe fetal rubella syndrome. ${ }^{6}$ The parents sued the mother's obstetrician both on behalf of their daughter and on their own, claiming that they would have terminated the pregnancy had the doctor informed them in a timely manner about the maternal infection and its likely effect on the fetus. The court granted the parents compensation for disability-related expenses but rejected the claim filed on behalf of the daughter. The verdict stated that life itself could not be considered a damage and that no third person was entitled to a value judgement about another person's life (this language was cited in the present case). The only limitation to this tenet that the court allowed for was a situation in which 'only individual vital functions can be sustained by artificial measures, without hope of improvement'. ${ }^{6}$

How does the current case, then, relate to the concept of wrongful life? It may be argued that there is a clear analogy between the two cases since in both instances the court had to decide whether survival with suffering constituted a damage when compared with the alternative of death. There are, however, also significant differences. Concerns about fetal interests cannot justify termination of pregnancy in German law. ${ }^{7}$ This is different from the case under discussion, where the patient's best interests (and not those of a third person) are the relevant standard. Also, the child in the wrongful life case would not have lived at all ex utero had the pregnancy been terminated, whereas the patient in the present case had already lived a long life. Finally, it seems difficult to equate the act of abortion with the withdrawal of a treatment that no longer benefits the patient. In its ruling, the Federal Court recognised these differences but stated that they did not permit to conclude that survival with suffering could be considered as a damage.

The second relevant concept the court evoked was value of life. In our case, the court ruled that no value judgements should be made about the life of another person. However, as some authors have shown, decisions to withdraw or withhold treatment at the end of life always entail value judgements about the patient's life, from the perspective of the decision-makers. ${ }^{8}$ Following this line of reasoning, it is important to be aware of the decision-makers' own subjectivity in order to balance his/her view against the patient's preferences and values. ${ }^{9}$ According to German law, if there is no way to infer a patient's will, either through an advance directive or a previous statement, a third person has to decide what would be in the best interests of the patient based on his/her previous values and beliefs. If family members, guardians and physicians cannot agree on a therapeutic strategy, a court will have to make that judgement. ${ }^{10}$ The court should take this decision with diligence and restraint, yet it is an illusion to believe that decisions about LST could be made free of value judgements.

Another way to approach this case is by focussing on medical indication. Professional guidelines regarding limitation of treatment state two things: (1) If there is no indication for an intervention, then physicians should not offer it, even if patients or families request it. ${ }^{511}$ (2) If the indication for a treatment already in place ceases to exist, then that treatment should be withdrawn. ${ }^{12}$ Along these lines, the Higher Regional Court argued that questions concerning the value of the patient's life should not be taken into account and that the only relevant question was whether there was a medical indication to provide CANH. ${ }^{4}$ If there was no clear indication-which the relevant professional societies $^{13} 14$ and the expert witnesses agreed on-then withdrawal of CANH should at least have been discussed.

Either way, the question of damage remains the most difficult one to discern. A conviction is only possible if damage is proven but in this particular case damage was taken to be the patient's survival. Establishing such a case goes against legal precedent in Germany. It is worth noting that there is reluctance to award damages for survival also in most other jurisdictions. ${ }^{15-17}$

What will be the effect of this verdict? This depends on the scope of its interpretation and application. It could be taken as encouraging physicians to always provide LST. However, we believe that this would be a misinterpretation. Current German laws and guidelines on end-of-life care clearly state that it is appropriate to withhold/withdraw LST (including CANH) in specific cases. ${ }^{10} 18$ If families/guardians and physicians agree to limit LST, no court approval is needed to do so. ${ }^{10}$ Furthermore, a ruling by the Federal Court in 2010 has upheld the right of families and physicians to withdraw LST. ${ }^{19}$ The court's refusal to grant damages for survival should not be interpreted as contradictory to the prevailing doctrine that withholding/withdrawing of LST is appropriate in specific cases. Rather, it marks a boundary to this tenet.

Ideally, the verdict would lead to a stronger focus on advance care planning, since one central problem in the present case was the impossibility to infer the patient's wishes and the lack of conversation between the family, guardian and health professionals.

Contributors Both authors developed the idea for and determined the scope of the article. UP did the literature review and wrote the first draft. Both authors revised the article.

Funding The authors have not declared a specific grant for this research from any funding agency in the public, commercial or not-for-profit sectors.

Competing interests None declared.

Patient consent for publication Not required.

Provenance and peer review Not commissioned; externally peer reviewed.

Data availability statement All data relevant to the study are included in the article

\section{ORCID iDs}

Ulrich Pfeifer http://orcid.org/0000-0002-2579-6397

Ruth Horn http://orcid.org/0000-0002-5714-3905

\section{REFERENCES}

1 BGH. Urteil vom 2. April 2019 - VI ZR 13/18, 2019. Available: http://juris bundesgerichtshof.de/cgi-bin/rechtsprechung/document.py?Gericht=bgh\&Art=en\& $\mathrm{aZ}=\mathrm{VI} \% 20 Z \mathrm{R} \% 2013 / 18 \& \mathrm{nr}=95016$ [Accessed 04 February 2020].

2 Achilles A, André F, eds. Bürgerliches Gesetzbuch nebst Einführungsgesetz: §§ 280, 823. 2nd ed. Berlin/Boston: De Gruyter, 2019.

3 München LG I. Endurteil v. 18.01.2017 - 90 5246/14 - 2017. Available: http://www gesetze-bayern.de/Content/Document/Y-300-Z-BECKRS-B-2017-N-112362?hl=true [Accessed 04 February 2020].

4 München OLG. Endurteil v. 21.12.2017 - 1 U 454/17 - 2017. Available: http://www. gesetze-bayern.de/Content/Document/Y-300-Z-BECKRS-B-2017-N-146433?hl=true\& AspxAutoDetectCookieSupport=1 [Accessed 04 February 2020].

5 Bundesärztekammer. Bekanntmachungen: Empfehlungen der Bundesärztekammer und der Zentralen Ethikkommission bei der Bundesärztekammer zum Umgang mit Vorsorgevollmacht und Patientenverfügung in der ärztlichen Praxis. Dtsch Arzteb/ 2010;107(18).

6 BGH. Urteil vom 18. Januar 1983 - VI ZR 114/81, BGHZ 86, 240-255: 8, 1983

7 Schönke A, Schröder H EA, et al. Strafgesetzbuch: \$218a. 30th edn. München: C.H. Beck, 2019.

8 Larcher V, Craig F, Bhogal K, et al. Making decisions to limit treatment in life-limiting and life-threatening conditions in children: a framework for practice. Arch Dis Child 2015;100(Suppl 2):s1-23.

9 Koogler TK, Wilfond BS, Ross LF. Lethal language, lethal decisions. Hastings Cent Rep 2003;33(2):37-41. 
10 Bundestag. Drittes Gesetz Zur Änderung des Betreuungsrechts. Bundesgesetzblatt Teil 1, NR. 48, 2009. Available: https://www.bgbl.de/xaver/bgbl/start.xav\#_bgbl_\% 2F\%2F*\%5B\%40attr_id\%3D\%27bgbl109s2286.pdf\%27\%5D_1580939661933 [Accessed 05 Feb 2020].

11 Borasio GD, Jox RJ. Choosing wisely at the end of life: the crucial role of medical indication. Swiss Med Wkly 2016;146:w14369.

12 American Medical Association. AMA code of medical ethics' opinions related to endof-life care. Chapter 5: opinions on caring for patients at the end of life. AMA Journal of Ethics 2018;20(8):E738-42.

13 Körner U, Biermann E, Bühler E, et al. DGEM-Leitlinie Enterale Ernährung:Ethische und rechtliche Gesichtspunkte. Akt Ernähr Med 2003;28:36-41.

14 Volkert D, Lenzen-Großimlinghaus R, Krys U, et al. Leitlinie Enterale Ernährung der DGEM und DGG:Enterale Ernährung (Trink- und Sondennahrung) in der
Geriatrie und geriatrisch-neurologischen Rehabilitation. Akt Ernähr Med 2004:29(4):198-225.

15 Perry R. It's a wonderful life: is it possible to say that a severely disabled child has been harmed by the mere fact of being born? Cornell Law Rev 2007;93(2):329-400.

16 Saitta NM, Hodge SD. What are the consequences of disregarding a "do not resuscitate directive" in the United States? Med Law 2013:32(4):441-58.

17 Sawicki NN. A new life for Wrongful living. N.Y. L. Sch. L. Rev 2014;58(279).

18 Bundesärztekammer. Grundsätze Der Bundesärztekammer Zur ärztlichen Sterbebegleitung. Dtsch Arzteb/ 2011;108(7):346-8.

19 BGH. Urteil vom 25. Juni 2010 - 2 StR 454/09, 2010. Available: http://juris. bundesgerichtshof.de/cgi-bin/rechtsprechung/document.py?Gericht=bgh\&Art=en\& $\mathrm{nr}=52999$ \&pos=0\&anz=1 [Accessed 4 Feb 2020]. 